\title{
Stopcock Device
}

National Cancer Institute

\section{Source}

National Cancer Institute. Stopcock Device. NCI Thesaurus. Code C50192.

A rotating device designed to act like a faucet for regulating the flow of a fluid. 